\title{
QUALITATIVE PARAMETERS OF PROTEIN GELS FROM ALBUMEN BASE
}

\author{
Sylvie Ondrušíková, Šárka Nedomová, Alžbeta Jarošová, Vojtěch Kumbár
}

\begin{abstract}
The aim of this research was to monitor strength of egg albumen gels depending on addition additives - salt, sugar, corn syrup, citric acid, citric acid in combination with sugar, whey protein and apple fiber. The egg albumen gel was prepared under two temperature limits at 70 and $90{ }^{\circ} \mathrm{C}$. The highest strengths of egg albumen gel were achieved at $90{ }^{\circ} \mathrm{C}$ in the albumen gel with the addition of $1 \%$ citric acid and $3.5 \%$ sugar with a strength of $7.38 \mathrm{~N}$, with the lowest strength of $1.61 \mathrm{~N}$ being achieved with the albumen gel with $0.1 \%$ salt. For an egg albumen gel prepared at $70{ }^{\circ} \mathrm{C}$, the strength ranged from $1.34 \mathrm{~N}(0.1 \%$ salt) to $6.63 \mathrm{~N}$ ( $1 \%$ citric acid $+3.5 \%$ sugar). On average, the $\mathrm{pH}$ of egg albumen gels ranged from 4.67 $(1 \%$ citric acid $+3.5 \%$ sugar $)$ to 9.05 ( $0.1 \%$ salt). For the strength of egg albumen gel and $\mathrm{pH}$ with additives of various additives at a given concentration, a statistically significant difference was found.
\end{abstract}

Keywords: hen eggs; albumen gel; strength; additives; texture analysis; temperature; $\mathrm{pH}$

\section{INTRODUCTION}

Egg albumen is one of the most important sources of animal proteins that make up the main component of dry matter, and their content ranges from 10 to $12 \%$ in native protein. Egg albumen is rich in ovalbumin (about 54\%), ovotransferrin (about 12\%), ovomucoid (about 11\%), and lysozyme (about 3.4\%) (Mine, 2002). It is gelation is a complex process involving protein denaturation, aggregation and formation of gel network (Mine, 1995). Egg proteins are especially valuable for the high content of essential amino acids that are essential for humans because they cannot synthesize themselves in the body. The digestibility of egg proteins is in the range of $98-100 \%$.

Eggs, especially egg albumen, have several functional properties that are used in the food industry. These properties include mainly gel forming ability, foaming capability and emulsifying properties. Changes in egg albumen during egg storage affect its functional properties (Mine and Yang, 2010; Wang et al., 2010). Most functional properties of egg white depend on exposure of hydrophobic groups, molecular surface and interactions of these groups (Li-Chan, Powrie and Nakai, 1995). Proteins produce gels by polymerization in a number of molecules, providing a three-dimensional network, and this process takes place by transforming a viscous liquid into a viscous elastic matrix (Hermansson, 1979). The formation of the gel structure takes place in two phases where the first phase involves changes in conformation (mostly induced by heat) or partial denaturation of protein molecules. In the protein dispersion thus formed, the first features of the elastic solid appeared. In the second stage, aggregation of denatured proteins results in increased viscosity and formation of a fixed network. The second phase should be slower to make a gradual build-up of the organized grid network, because if accelerated at this stage, a non-organized structure would form, a coagulum that would not be able to retain water, which would lead to syneresis. The nature and properties of egg whites may be affected by several factors, predominantly protein concentration and $\mathrm{pH}$ values of the solution. Egg albumen gel formation can be conditioned by the use of both heating and cooling, depending on the nature of the protein and the process itself (Alleoni, 2006).

The ability to coagulate egg albumen is used in many food products - such as surimi, baker's products, desserts, meat products and currently in very popular foods called "superfoods" with a high protein content, which important especially for athletes or people with alternative diets. Commercially available egg albumen products have a wide range of uses and are produced in various shapes (dice, burgers, rollers). These products can be enriched with other nutritionally valuable substances, such as fiber (Zayas, 1997).

Egg albumen coagulates at $\mathrm{pH} 7$ from $65.0^{\circ} \mathrm{C}$ and at $\mathrm{pH} 9$ to $69.5{ }^{\circ} \mathrm{C}$. The ability of egg albumen coagulation is utilized in many food products (Croguennec, Nau and Brulé, 2002). The albumen is brought to a solid state at a temperature of $61-70{ }^{\circ} \mathrm{C}$. At $70-74{ }^{\circ} \mathrm{C}$, the gel increases elasticity and stabilizes the gel at $89{ }^{\circ} \mathrm{C}$. The strongest albumen gels are in the temperature range of $71-83{ }^{\circ} \mathrm{C}$ (Simeonovová et al., 2013). Factors influencing gel formation are temperature, warm-up time, $\mathrm{pH}$ value and ionic strength. Egg protein properties change due to chemical changes in glycoprotein and ovomucin (Kirunda and McKee, 2007). These changes lead to 
a decrease in the height of the solid egg by lowering its viscosity and losing its gel-like structure (Hammershøj and Quist, 2001; Lomakina and Míková, 2006). The egg albumen gels are produced without flavour and with flavours in a salty and sweet form. They can be used in cold kitchens (e.g. grated, salad cuts) or in hot kitchens (they can be baked, choked, cooked). The addition carbohydrates and/or salt in products are common in the food industry and therefore it is important to consider their effect with respect to protein gel formation (Raikos, Campbell and Euston, 2007).

Gelling traditionally requires warming, but can also be caused by high pressure, acidification, enzymatic amplification, salt or urea use. The characteristics of each gel are different and depend on the degree of degradation and protein concentration (Kaewmanee, 2010).

Texture is one of the major quality factors in foods in addition to appearance, flavour and nutrition. In many cases, sensory texture is correlated with rheological properties measured by instruments (Pollak and Peleg, 1982). The quality of the resulting egg albumen gel is evaluated mainly by its strength.

\section{Scientific hypothesis}

The main hypothesis of this work is detection of dependence of egg albumen gel strength, $\mathrm{pH}$ and height on species and amount of addition.

\section{MATERIAL AND METHODOLOGY}

For the determination of the strength of the egg albumen gel were use hen eggs, hybrid Hisex Brown from a commercial breeding from South Moravia, Czech Republic. The hens were fed a complete feed mixture. Hen eggs were imported on a laying day and stored at $4{ }^{\circ} \mathrm{C}$ and $75 \%$ relative humidity. For fortification was used different salt additions (0.1 and $0.4 \%)$, sugar (10\%), corn syrup $(10 \%)$, citric acid $(1 \%)$, citric acid in combination with sugar $(1+3.5 \%)$, whey protein (1 and 3\%), apple fiber (1 and 3\%), where the strength of the egg gel was determined.

The egg albumen gel was made from the fresh eggs, where the egg was manually crushed, and the individual egg components were separated. The egg albumen was thoroughly homogenized, and the additive was added thereto at a certainly concentration. The albumen protein preparation thus prepared was poured into the sampler and placed in a water bath at $90{ }^{\circ} \mathrm{C}$ for $30 \mathrm{~min}$ and for comparison at $70^{\circ} \mathrm{C}$ for $30 \mathrm{~min}$. For measuring the strength of the gel, a universal instrument for measuring physical characteristics - TIRAtest (type 27025, TIRA, Germany) was used. A flat-plate pressure test with a crossbar speed of $100 \mathrm{~mm} \cdot \mathrm{min}^{-1}$ was performed using this instrument. From each gel was cut 8 cylinders with a height and a diameter of $1 \mathrm{~cm}$.

The concentration of hydrogen ions is expressed by the hydrogen exponent $(\mathrm{pH})$, which is negative logarithm of hydrogen ion concentration. Digital $\mathrm{pH}$ was used for determination PORTAMESS $911 \mathrm{pH}$ KNICK with injection electrodes and the height of the egg albumen gels was measured with a sliding gauge.

\section{Statistic analysis}

Statistical analysis of the differences was based on Statistica12 (StatSoft, Czech Republic), namely singlefactor ANOVA - Duncan's test. Microsoft Excel version 2010 (Microsoft, USA) was used to evaluate the results. The statistically inconclusive difference was considered to be a result whose probability value reached $p>0.05$.

\section{RESULTS AND DISCUSSION}

In this study, we focused on proteins precisely albumen gels on egg albumen base. Additives were added to the homogeneity of the egg albumen mixture at a given concentration. As standard in this case, the egg albumen was used without any addition. The strengths of the egg albumen gel at a preparation temperature of $90{ }^{\circ} \mathrm{C}$ are shown in Table 1. Strengths was observed in the specimens thus prepared, when the result showed that the highest value was achieved by the gels with the addition of $1 \%$ citric acid $+3.5 \%$ sugar $(7.38 \mathrm{~N})$ and the lowest values were achieved in egg albumen gels with the addition of $0.1 \%$ salt $(1.61 \mathrm{~N})$.

Compared to the standard pure egg albumen gel, the highest value increased by $4.71 \mathrm{~N}$ and the lowest value dropped by $1.05 \mathrm{~N}$. When using a lower sample temperature $\left(70{ }^{\circ} \mathrm{C}\right)$, there were very similar results when the highest strength of the egg albumen gel was achieved in the sample with $1 \%$ citric acid $+3.5 \%$ sugar and the lowest value in the sample with $0.1 \%$ salt. Raikos, Campbell and Euston (2007) says that the highest achieved strength of the egg albumen gel with the addition of 3\% sugar $+3 \%$ salt when the value is $14.21 \mathrm{~N}$, which is higher than our results by $48 \%$. Adding $1 \%$ apple fiber to albumen gel strength increased by $1.56 \mathrm{~N}$ over egg albumen gel without addition at $90{ }^{\circ} \mathrm{C}$. Higher amounts of fiber resulted in a decrease in the strength of the protein by $0.61 \mathrm{~N}$. Similarly, an albumen gel prepared at $70^{\circ} \mathrm{C}$ was obtained when the addition of $1 \%$ of apple fiber increased the egg albumen gel strength by $2.03 \mathrm{~N}$ against the gel without addition.

When comparing the results of the egg albumen gel strength at 90 and $70{ }^{\circ} \mathrm{C}$, it can be seen that the lower strength of the resulting albumen gel occurred at a lower sample preparation temperature. On the other hand, the lowest value was achieved by in its results in the sample with the addition of $6 \%$ salt, where the value was $4.66 \mathrm{~N}$ (Raikos, Campbell and Euston, 2007). This value approximated our results for egg albumen gels with the addition of $1 \%$ whey protein $(4.60 \mathrm{~N})$ at $90{ }^{\circ} \mathrm{C}$ and at $70{ }^{\circ} \mathrm{C}$ for samples with $1 \%$ citric acid $(4.86 \mathrm{~N})$ added.

Holt et al. (1984) showed egg albumen gel strength were highest in gels with a treatment combination of $85.2^{\circ} \mathrm{C}, \mathrm{pH}$ 9.0, and $0.08 \mathrm{M} \mathrm{NaCl}$. Temperature had the greatest effect on all three rheological parameters. Gels heated above 80 ${ }^{\circ} \mathrm{C}$ were of unusual character, exhibiting syneresis and shrinkage. The average $\mathrm{pH}$ values of egg albumen gel with additive additions in a given concentration are shown in Table 2. Croguennec, Nau and Brulé (2002) states that the highest strength of the egg albumen gel occurs at $\mathrm{pH} 5$, resulting in gross aggregation, and the resulting coagulate has a low viscoelastic property whereas egg albumen gels at $\mathrm{pH} 7$ and 9 are more viscoelastic. The highest strength values for egg albumen gel were obtained at $\mathrm{pH} 9.05(0.1 \%$ salt) and the lowest ones at $\mathrm{pH} 4.67$ (1\% citric acid $+3.5 \%$ sugar). 
Handa et al. (1998) showed that at $\mathrm{pH} 7$ and 9 had egg albumen gels a fine and uniform network structure that may have contributed to the excellent gel properties. It is clear from our results that the additive additives we have chosen, have a significant effect on the measured $\mathrm{pH}$ values, when compared to the standard which was 9.04 for the egg albumen gel without addition, the average $\mathrm{pH}$ values ranged from 9.05 to 4.67. Li et al. (2018) states that $\mathrm{pH}$ values also had affect eggs' other functional properties as a foam and foam stability.

Egg albumen gel height values (Table 3) were also observed, with the highest value achieved by the albumen gel with the addition of $1 \%$ citric acid $+3.5 \%$ sugar
$(4.23 \mathrm{~cm})$ and the lowest value of $1.98 \mathrm{~cm}$ protein albumen gel with the addition of $10 \%$ corn syrup.

Between individual samples a statistically significant difference was observed due to different $\mathrm{pH}$ values. Adding $1 \%$ whey protein reduced the egg albumen gel height by 0.8 $\mathrm{cm}$. However, after the addition of $3 \%$ whey protein, the height increased by $0.31 \mathrm{~cm}$ in the sample at $90{ }^{\circ} \mathrm{C}$. Egg albumen gel height results correspond to $\mathrm{pH}$ values, where it can generally be said that lower height albumen gel has been reached in the alkaline environment than in the acidic environment.

\begin{tabular}{ccc} 
Table 1 Effect of type and amount of addition additives on egg albumen gel strength at 90 and $70{ }^{\circ} \mathbf{C}$. \\
\hline Quantity and type of addition & Strength $[\mathbf{N}] \mathbf{9 0}{ }^{\circ} \mathbf{C}$ & Strength $[\mathbf{N}] \mathbf{7 0}^{\circ} \mathbf{C}$ \\
\hline Without addition & $2.66^{\mathrm{b}, \mathrm{c}}$ & $1.98^{\mathrm{b}}$ \\
$0.1 \%$ salt & $1.61^{\mathrm{e}}$ & $1.34^{\mathrm{c}}$ \\
$0.4 \%$ salt & $2.55^{\mathrm{b}}$ & $1.76^{\mathrm{a}}$ \\
$10 \%$ sugar & $3.13^{\mathrm{a}, \mathrm{c}}$ & $2.56^{\mathrm{a}, \mathrm{b}}$ \\
$1 \%$ apple fiber & $4.22^{\mathrm{d}}$ & $3.01^{\mathrm{d}}$ \\
$3 \%$ apple fiber & $3.61^{\mathrm{a}}$ & $3.15^{\mathrm{c}}$ \\
$1 \%$ citric acid & $5.56^{\mathrm{f}}$ & $4.86^{\mathrm{e}}$ \\
$1 \%$ citric acid + 3.5\% sugar & $7.38^{\mathrm{g}}$ & $6.63^{\mathrm{c}, \mathrm{e}}$ \\
$1 \%$ whey protein & $4.60^{\mathrm{d}}$ & $4.11^{\mathrm{d}}$ \\
$3 \%$ whey protein & $3.35^{\mathrm{a}, \mathrm{d}}$ & $2.57^{\mathrm{a}, \mathrm{c}}$ \\
$10 \%$ corn syrup & $3.38^{\mathrm{a}}$ & $3.08^{\mathrm{a}}$
\end{tabular}

Note: $\mathrm{a}, \mathrm{b}, \mathrm{c}, \mathrm{d}, \mathrm{e}, \mathrm{f}, \mathrm{g}$ - different superscripts in a line indicate a statistically significant difference at $p<0.05$.

Table 2 Effect of type and amount of addition additives on $\mathrm{pH}$ value egg albumen gel.

\begin{tabular}{cc}
\hline Quantity and type of addition & pH [-] \\
\hline Without addition & $9.04^{\mathrm{a}}$ \\
$0.1 \%$ salt & $9.05^{\mathrm{a}}$ \\
$0.4 \%$ salt & $9.04^{\mathrm{a}}$ \\
$10 \%$ sugar & $8.94^{\mathrm{a}}$ \\
$1 \%$ apple fiber & $8.77^{\mathrm{c}}$ \\
$3 \%$ apple fiber & $8.23^{\mathrm{b}}$ \\
$1 \%$ citric acid & $5.08^{\mathrm{d}}$ \\
$1 \%$ citric acid + 3.5\% sugar & $4.67^{\mathrm{a}}$ \\
$1 \%$ whey protein & $6.75^{\mathrm{c}}$ \\
$3 \%$ whey protein & $7.23^{\mathrm{b}}$ \\
$10 \%$ corn syrup & $6.79^{\mathrm{b}}$ \\
\hline
\end{tabular}

Note: $\mathrm{a}, \mathrm{b}, \mathrm{c}, \mathrm{d}$ - different superscripts in a line indicate a statistically significant difference at $p<0.05$.

Table 3 Effect of type and amount of addition additives on height of the egg albumen gel.

\begin{tabular}{ccc}
\hline Quantity and type of addition & $\begin{array}{c}\text { Height of the egg albumen } \\
\text { gels } \mathbf{9 0}{ }^{\circ} \mathbf{C}[\mathbf{c m}]\end{array}$ & $\begin{array}{c}\text { Height of the egg albumen gels } \\
\mathbf{7 0}{ }^{\circ} \mathbf{C}[\mathbf{c m}]\end{array}$ \\
\hline Without addition & $2.45 \mathrm{a}, \mathrm{b}$ & $2.38 \mathrm{a}, \mathrm{b}$ \\
$0.1 \%$ salt & $2.43 \mathrm{a}, \mathrm{b}$ & $2.42 \mathrm{a}, \mathrm{b}$ \\
$0.4 \%$ salt & $2.51 \mathrm{a}, \mathrm{b}$ & $2.48 \mathrm{a}, \mathrm{b}$ \\
$10 \%$ sugar & $2.49 \mathrm{a}, \mathrm{b}$ & $2.47 \mathrm{a}, \mathrm{b}$ \\
$1 \%$ apple fiber & $2.52 \mathrm{a}, \mathrm{b}$ & $2.50 \mathrm{a}, \mathrm{b}$ \\
$3 \%$ apple fiber & $2.75 \mathrm{a}$ & $2.73 \mathrm{a}$ \\
$1 \%$ citric acid & $3.78 \mathrm{c}$ & $3.78 \mathrm{c}$ \\
$1 \%$ citric acid $+3.5 \%$ sugar & $4.23 \mathrm{~d}$ & $4.22 \mathrm{~d}$ \\
$1 \%$ whey protein & $2.37 \mathrm{a}, \mathrm{b}$ & $2.33 \mathrm{a}, \mathrm{b}$ \\
$3 \%$ whey protein & $2.68 \mathrm{a}$ & $2.66 \mathrm{a}$ \\
$10 \%$ corn syrup & $1.98 \mathrm{~b}$ & $2.00 \mathrm{~b}$
\end{tabular}

Note: $\mathrm{a}, \mathrm{b}, \mathrm{c}, \mathrm{d}$ - different superscripts in a line indicate a statistically significant difference at $p<0.05$. 


\section{CONCLUSION}

There was monitored the effect of influence of the type and amount of additive additions on the rheological properties especially strength, height and $\mathrm{pH}$ of the egg albumen protein gels using two temperature stages of sample preparation.

Average egg albumen gel strength values ranged from $1.61 \mathrm{~N}(0.1 \%$ salt $)$ to $7.38 \mathrm{~N}$ (1\% citric acid $+3.5 \%$ sugar $)$ for samples prepared at $90{ }^{\circ} \mathrm{C}$. A native egg albumen gel sample was considered as standard without an additive addition having an average strength of $2.66 \mathrm{~N}$. The closest to this strength was a sample of the albumen gel with the addition of $0.4 \%$ salt with an average value of $2.55 \mathrm{~N}$.

For egg albumen gels prepared at $70{ }^{\circ} \mathrm{C}$, average gel strengths were in the range of $1.34 \mathrm{~N}(0.4 \%$ salt $)$ to $6.63 \mathrm{~N}$ ( $1 \%$ citric acid $+3.5 \%$ sugar). As a standard, native albumen gel was using again without addition of additives with an average value of $1.98 \mathrm{~N}$, which was again most closely approximated by egg albumen gel with the addition of $0.4 \%$ salt $(1.76 \mathrm{~N})$.

Changes in $\mathrm{pH}$ values were also observed for samples after the addition of selected additives, with an average value of 9.04 in the non-admixture of the albumen gel sample. The same values were obtained with a sample of $0.4 \%$ by the addition of salt. The highest average $\mathrm{pH}$ was achieved by the sample with $0.1 \%$ salt addition and the lowest $\mathrm{pH}$ sample with $1 \%$ citric acid $+3.5 \%$ sugar (4.67).

It can be stated that the various additive additives significantly affect the functional properties of hen egg masses and the egg albumen gel, which can be used in innovations and the creation of new recipes for the food industry.

\section{REFERENCES}

Alleoni, A. C. C. 2006. Albumen protein and functional properties of gelation and foaming. Scientia Agricola, vol. 63, no. 3 , p. 291-298. https://doi.org/10.1590/S010390162006000300013

Croguennec, T., Nau, F., Brulé, G. 2002. Influence of pH and Salts on Egg White Gelation. Journal of Food Science, vol. 67, no. 2 , p. 608-614. https://doi.org/10.1111/j.13652621.2002.tb10646.x

Hammershøj, M., Quist, K. B. 2001. Importance of hen age and egg storage time for egg albumen foaming. Food Science and Technology-Zurich, vol. 34, no. 2, p. 118-120.

Handa, A., Takahashi, K., Kuroda, N., Froning, G. W. 1998. Heat-induced egg white gels as affected by $\mathrm{pH}$. Journal of Food Science, vol. 63, no. 3, p. 403-407. https://doi.org/10.1111/j.1365-2621.1998.tb15752.x

Hermansson, A. M. 1979. Aggregation and denaturation involved in gel formation. In Pour-El, A. Functionality and Protein Structure. Washington, USA : American Chemical Society, vol. 92, p. 81-103. ISBN 13: 9780841204782. https://doi.org/10.1021/bk-1979-0092.ch005

Holt, D. L., Watson, M. A., Dill, C. W., Alford, E. S., Edwards, R. L., Diehl, K. C., Gardner, F. A. 1984. Correlation of the rheological behavior of egg albumen to temperature, $\mathrm{pH}$, and $\mathrm{NaCl}$ concentration. Journal of Food Science, vol. 49, no. 1 , p. 137-141. https://doi.org/10.1111/j.13652621.1984.tb13690.x

Kaewmanee, T. 2010. Impact of Salting on Chemical Compositions, Physicochemical and Functional Properties of Duck Egg : PhD Thesis. Chang Wat Songkhla, Thailand : Prince of Songkla University. 256 p.
Kirunda, D. F. K., McKee, S. R. 2007. Relating quality characteristics of aged eggs and fresh eggs to vitelline membrane strength as determined by a texture analyzer. Poultry Science, vol. 79, no. 8, p. 1189-1193. https://doi.org/10.1093/ps/79.8.1189

Li, J., Wang, C., Li, X., Su, Y., Yang, Y., Yu, X. 2018. Effects of $\mathrm{pH}$ and $\mathrm{NaCl}$ on the physicochemical and interfacial properties of egg white/yolk. Food bioscience, vol. 23, p. 115120. https://doi.org/10.1016/j.fbio.2017.12.004

Li-Chan, E. C., Powrie, W. D., Nakai, S. 1995. The chemistry of eggs and egg products. Egg Science and Technology, vol. 4, p. 105-75.

Lomakina, K., Míková, K. 2006. A study of the factors affecting the foaming properties of egg white-a review. Czech Journal of Food Sciences, vol. 24, no. 3, p. 110-118.

Mine, Y. Recent advances in egg protein functionality in the food system. 2002. World's poultry science journal, vol. 58, no. 1, p. 31-39. https://doi.org/10.1079/WPS20020005

Mine, Y. Recent advances in the understanding of egg white protein functionality. 1995. Trends in Food Science and Technology, vol. 6 , no. 7 , p. 225-232. https://doi.org/10.1016/S0924-2244(00)89083-4

Mine, Y., Yang, M. 2010. Functional properties of egg components in food systems. In Guerrero-Lagarreta, I. Handbook of Poultry Science and Technology. Hoboken, USA : John Wiley \& Sons, vol. 1, 579-630 p. ISBN: 9780470185520 .

https://doi.org/10.1002/9780470504451.ch29

Pollak, N. T., Peleg, M. 1982. Early indications of failure in large compressive deformation of solid foods. Journal of Food Science, vol. 45 , no. 4, p. 825-830. https://doi.org/10.1111/j.1365-2621.1980.tb07459.x

Raikos, V., Campbell, L., Euston, S. R. 2007. Rheology and texture of hen's egg protein heat-set gels as affected by $\mathrm{pH}$ and the addition of sugar and/or salt. Food Hydrocolloids, vol. 21, no. $2,237-244$. https://doi.org/10.1016/j.foodhyd.2006.03.015

Simeonovová, J., Míková, K., Kubišová, S., Ingr, I. 2013. Technology of poultry, eggs and minority animal products (Technologie drůbeže, vajec a minoritnich živočišných produktü). $2^{\text {nd }}$ ed. Brno, Czech Republic : Mendelova univerzita v Brně, 241 p. ISBN 978-80-7375-891-2. (In Czech)

Wang, Z. G., Pan, X. J., Zhang, W. Q., Peng, Z. Q., Zhao, R. Q., Zhou, G. H. 2010. Methionine and selenium yeast supplementation of the maternal diets affects antioxidant activity of breeding eggs. Poultry Science, vol. 89, no. 5, p. 931-937. https://doi.org/10.3382/ps.2009-00268

Zayas, J. F. 1997. Foaming properties of proteins. In: Functionality of proteins in food. Heidelberg, Germany : Springer, 260-309 p. ISBN 978-3-642-63856-5.

\section{Acknowledgments:}

This research was supported by AF-IGA-2019/042 "Qualitative parameters of protein gels based on hen eggs albumen" financed by Internal Grant Agency FA MENDELU.

This research was carried out in Biotechnology Pavilion M, financed by the OP VaVpI CZ.1.05/4.1.00/04.0135 project at the Department of Food Technology at Mendel University.

\section{Contact address:}

Ing. Sylvie Ondrušíková, Mendel University in Brno, Faculty of AgriSciences, Department of Food Technology, Zemědělská 1, 61300 Brno, Czech Republic, Tel.: +420 545133 262, E-mail: sylvie.ondrusikova@mendelu.cz 
*doc. Ing. Šárka Nedomová, Ph.D., Mendel University in Brno, Faculty of AgriSciences, Department of Food Technology, Zemědělská 1, 61300 Brno, Czech Republic, Tel.: +420 545133 193, E-mail: snedomov@mendelu.cz prof. Ing. Alžbeta Jarošová, Ph.D., Mendel University in Brno, Faculty of AgriSciences, Department of Food Technology, Zemědělská 1, 61300 Brno, Czech Republic, Tel.: $\quad+420 \quad 545 \quad 133 \quad$ 563, E-mail: alzbeta.jarosova@mendelu.cz doc. Ing. Vojtěch Kumbár, Ph.D., Mendel University in Brno, Faculty of AgriSciences, Department of Technology and Automobile Transport, Zemědělská 1, 61300 Brno, Czech Republic, Tel.: +420 545132 128, E-mail: vojtech.kumbar@mendelu.cz

Corresponding author: * 